\title{
Small Scale Physical Measurement of Wave Overtopping For Different Shore Protection Structures
}

\author{
Farhood Azarsina*, Aria Pirzadeh, Ghasem Darvish
}

Department of Marine Structures, Faculty of Engineering, Science and Research Branch, Islamic Azad University, Tehran, Iran. Postal code: 1477893855

*Corresponding author's Email: F.Azarsina@srbiau.ac.ir

\section{ARTICLE INFO}

Article History:

Received: 4 Jun 2019

Accepted: 5 Sep. 2019

\section{Keywords:}

Shore protecting structure

Seawall

Wave-structure interaction

Small wave flume

Wave overtopping

Wave run-up

\begin{abstract}
Using artificial constructions is one of the most important ways to protect shores against wave actions and the consequent erosion. Due to costly nature of large scale marine projects, it is considered an efficient approach to study small scale model of the structure for simulation of sea conditions, measurement of hydraulic parameters and wave-structure interactions.

In present research, construction of a small wave flume has been reported. Water up to $15 \mathrm{~cm}$ deep is filled in the flume and a DC motor directly rotates a flap in oscillations as a result of which regular waves of less than $10 \mathrm{~cm}$ height are produced. Wave lengths are around one meter, and wave periods are about one second. High quality fast images were analyzed in order to characterize the waves.

Test runs were performed with different combinations of the wave parameters and the water depth, on five different revetments including: vertical seawall, simple slope, stepped slope, curved and recurved. Wave discharge with the aid of a small reserve tank at the far end of flume was measured. Results show that the recurved structure for most of the test cases reduce the wave overtopping to zero. The stepped slope has an efficient performance in dissipating the wave energy and reducing the wave run-up and overtopping. Simple slope recorded maximum discharge. Curved structure creates a water column of high speed vertical jet, and lastly the vertical seawall undergoes severe wave impact. Quantitative test results have been compared with well-known Owen's formula for wave overtopping.
\end{abstract}

\section{Introduction}

Natural shorelines undergo complex morphodynamic and erosion processes. The waves that transmit from deep water to shallow coastal region are described in terms of wave shoaling and refraction; conservation of energy relates the wave parameters in deep water and any station in shallow water [1]. Refraction coefficient and the shoaling coefficient parameterize these relations. In a case that wave rays progress perpendicular to a straight shoreline with uniform bottom slope, no refraction occurs, i.e. waves progress along their straight ahead path. In this case, shoaling coefficient is the only factor that describes the change in the wave height as it enters the surf zone. At some depth the wave profile will become unstable and asymmetric with respect to its face and back and it will "break". Wave breaking has been extensively reviewed in the literature [2].

Man-made structures, however, can interrupt these natural phenomena. Five types of shore protection structures that have been experimented in our small wave flume are respectively discussed in the following paragraphs:

1. A vertical seawall exposed to incident waves will reflect most of the energy, and therefore a standing wave of up to twice the height of incident and reflected waves is made [3]. Such a case is inhibiting for marine operations alongside the wall. The wave run-up on the seawall increases to a point that water level exceeds the freeboard of the wall and the shore behind will be inundated.

2. Historically, sloped revetments have been in common use. They are a more pronounced barrier than the natural seabed slope. A 1:10 bottom slope is fairly mild, while a man-made slope may be as large as 1:1. The steeper it gets, the more wave reflection happens; in limit a 90 degree slope is a vertical seawall that may completely reflect the incoming waves. The less steep slope, will transmit more energy over it, thus will be less effective as a barrier. 
3. Added to a slope, steps are very effective in wave dissipation. While the wave interacts with a stepped slope, the water tongue must conquer every step as it elevates the slope. Water surface, which in theory is formally described by the kinematic and dynamic free surface boundary conditions, is excitingly seen a parallel to the step pattern.

4. A curved profile that resembles a skateboarding stage, jets the water flux upward. As a result the horizontal passage of wave is reduced.

5. Finally, a reverse curve will excite a jet in negative horizontal direction. This would be the most effective way to prevent wave overtopping, as will be seen in the present test results. In this case, wave load on the structure is also reduced because the structure returns the positive wave momentum in negative direction and therefore except than a very instant, the barrier has not to endure a stagnating momentum.

Literature of wave overtopping is very rich, and from the many references the following brief summary is introduced:

A. Coastal Engineering Manual notes that a wave overtopping occurs if the maximum wave run-up exceeds the crest height of the structure's freeboard ([2], Part VI, Chapter 5). Then critical values of overtopping discharge is defined for different application; a discharge as little as one litre per second per unit length of structure can be unsafe for vehicles and very dangerous for pedestrians, while for revetments a discharge up to 50 liters/s per $\mathrm{m}$ is admissible ([2], Table VI-5-6).

B. It is important to know that high instantaneous loads are not covered by average overtopping rates. Instantaneous loads due to wave overtopping can be described by layer thicknesses and overtopping velocities [4]. Wave overtopping can be separated in four processes:

- "incoming waves at the dike toe

- wave motion and wave run-up on the seaward slope

- wave overtopping on the dike crest

- wave overtopping on the landward slope." [4]

C. Empirical formulas for predicting the wave overtopping have been summarized in Table VI-57 of [2]. They are of two types, either:

$Q=a e^{-b R}$

or

$Q=a R^{-b}$.

Where $Q$ is average nondimensional overtopping per unit length of structure, and $R$ is nondimensional freeboard height most simply defined as $R=R_{c} / H_{s}$ with $R_{c}$ being freeboard (height of structure's crest above still-water-level), and $H_{s}$ significant wave height.

One of the most well-known overtopping formulas is the Owen's formula [5], [6]. It is written as follows: $\frac{q}{g H_{s} T_{0 m}}=\mathrm{a} \exp \left(-\mathrm{b} \frac{R_{c}}{H_{s}} \sqrt{\frac{s_{0 m}}{2 \pi}} \frac{1}{\gamma_{r}}\right)$

Where $s_{0 m}$ is the average wave steepness in deep water, $T_{0 m}$ is the peak period of a wave spectrum, $\gamma_{\mathrm{r}}$ is a factor representing the roughness and porosity of the structure surface, and is taken unity for a smooth and nonporous surface. Factors $a$ and $b$ in Eq. (3) depend on slope and are defined in Table 1.

Table 1. Factors in Owen's overtopping formula adapted from [2]

\begin{tabular}{ccc} 
Slope & $\mathrm{a}$ & $\mathrm{b}$ \\
\hline $1: 1$ & 0.008 & 20 \\
$1: 1.5$ & 0.010 & 20 \\
$1: 2$ & 0.013 & 22 \\
$1: 3$ & 0.016 & 32 \\
$1: 4$ & 0.019 & 47 \\
\hline
\end{tabular}

D. Overtopping measurements in prototype scale have been previously reported. The European project that studied the Zeebrugge breakwater is an example [7]. Large scale models can closely simulate the prototype. LARGE WAVE CHANNEL (GWK) test facility in Leibniz University Hannover was used to perform experiments on the Zeebrugge breakwater [8]. Small scale wave flumes have been used for such measurements as well. A 1:30 scale of the Zeebrugge breakwater was also tested in small wave flume of Ghent University $15 \mathrm{~m}$ long, $0.35 \mathrm{~m}$ wide and $0.6 \mathrm{~m}$ high [8]. Another example of extensive small scale experiments for the study of wave overtopping is in reference [9].

The composition of this paper is as follows:

- Design, construction and assembly of the wave flume are presented in subsection 2.1 Design and Construction of the Wave Flume.

- The inputs to the wavemaker are calibrated and wave profiles analyzed in subsection 2.2 Input Wave Analysis.

- Design of experiments and analysis of the wave overtopping outputs are presented in section Results and Discussion.

\section{Materials and Methods}

\subsection{Design and Construction of the Wave Flume}

With regard to flume construction costs, its structural integrity and mobility, dimensions length $1.8 \mathrm{~m}$, width and height 30 by $30 \mathrm{~cm}$ were selected. Maximum water depth of $24 \mathrm{~cm}$ is assumed. Then water content inside the flume is 129.6 litres:

$$
\begin{gathered}
L \times B \times d=180 \times 30 \times 24=129600 \mathrm{~cm}^{3} \\
=129.6 \mathrm{lit}
\end{gathered}
$$

Therefore in full condition, the flume must support a distributed load of $129.6 \mathrm{~kg}$ :

$\mathrm{w}=\frac{129.6 \mathrm{~kg}}{1.8 \mathrm{~m}}=72 \mathrm{~kg} / \mathrm{m}$

Such dimensions have been observed in similar small scale wave flumes that are used for educational demo 
and preliminary research objectives; e.g. the UK based company JBA consulting at the University of Leeds [10].

Based on this, a strong structure with multiple supports in length is required.

According to deep and shallow water definition, $\frac{\mathrm{d}}{\lambda} \geq$ 0.5 is deep water, $\frac{d}{\lambda} \leq 0.05$ is shallow water and in between is intermediate depth.

So in $24 \mathrm{~cm}$ water depth, a wave length of $\lambda \leq 48 \mathrm{~cm}$ is in deep water and $\lambda \geq 480 \mathrm{~cm}$ is shallow. Clearly, shallow water criterion is not satisfied in this flume.

It is decided that wave-maker to be a paddle type with its pivot on top - out of water -, so the driving engine and shaft need not to be waterproof. The paddle oscillates with $\mathrm{S} / 2$ stroke and at frequency $\sigma$ as follows:

$\mathrm{x}=\frac{\mathrm{S}(\mathrm{z})}{2} \sin \sigma \mathrm{t}$

Where $\mathrm{z}$ axis is positive upward and origin of coordinate is at water level. For a bottom pivoted paddle the kinematics of paddle and the resulting surface wave was solved according to potential theory in chapter six of [1].

The following equation for a known volume of displaced water approximates the relation between the ratio of wave height to paddle stroke and the wave length (again this is for a bottom-hinged paddle):

$\frac{\mathrm{H}}{\mathrm{S}}=\frac{\mathrm{kd}}{2}$

Wave dispersion relation, on the other hand, is analyzed to evaluate the wave frequency:

\section{$\sigma^{2}=$ gk tanh kd}

With regard to the curve in [1] dimensionless mean power for flap wavemaker has a maximum value of

$\left(\frac{\mathrm{P}}{\rho \mathrm{g} \frac{\mathrm{S}^{2} \mathrm{~d}}{\mathrm{~T}}}\right)_{\text {max }} \approx 0.23$.

In summary, wavemaker data for a water depth of 24 $\mathrm{cm}$ were approximated and an electric motor of appropriate power was selected. Due to margin of safety for the electric engine, tests however were performed in smaller water depth. Figure 1 shows the small portable wave flume.

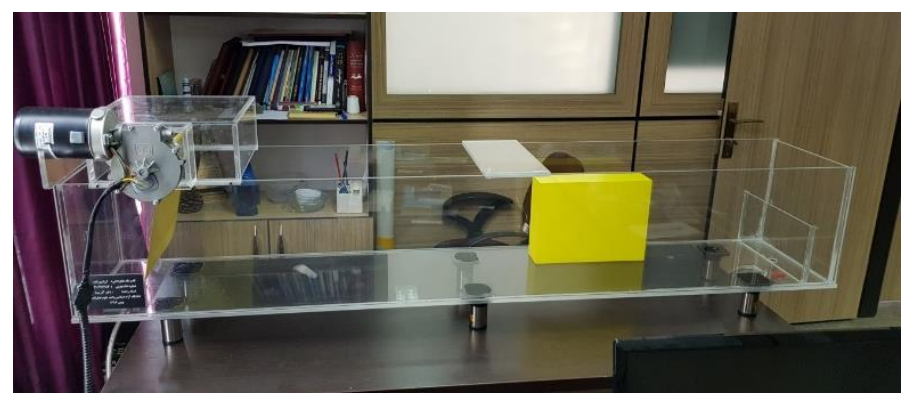

Figure 1. Small portable wave flume with vertical seawall and the overtopping measurement tank and the top-hinged flap and the electric motor.
Details of geometry of five tested seawalls were designed according to [11].

Model scale for a typical case is assumed to be 1:20. Therefore a $3 \mathrm{~m}$ water depth at the breakwater's toe in real scale converts to $15 \mathrm{~cm}$ in the flume. Structure's crest height is $22.5 \mathrm{~cm}$ in model scale, equivalent to 4.5 $\mathrm{m}$ in the full scale revetment.

Two water levels 15 and $13 \mathrm{~cm}$ equivalent to $3 \mathrm{~m}$ and $2.6 \mathrm{~m}$ depths in prototype were tested.

Surface gravity waves govern the physical phenomena inside the flume; therefore, Froude's similarity rule is used [9]. Table 2 is a summary of the problem scales.

Froude numbers between model and full scale are satisfied when velocities as well as time are proportional to root square of the length scale. Masses are scaled by third power of the length. Overtopping, i.e. water flux over the structure's crest, has proportions of velocity multiplied by area. Area equals a unit length of the structure multiplied by the overtopping water depth. Thus, overtopping scale is a length scale multiplied to a velocity scale.

Table 2. Geometric, kinematic and dynamic scales

\begin{tabular}{cc}
\hline Length ratio & $\mathrm{L}_{\mathrm{R}}=20$ \\
\hline Velocity ratio & $\mathrm{V}_{\mathrm{R}}=4.47$ \\
\hline Time ratio & $\mathrm{T}_{\mathrm{R}}=4.47$ \\
\hline Mass ratio & $\mathrm{M}_{\mathrm{R}}=8000$ \\
\hline Overtopping ratio (per unit length of structure) & $\mathrm{Q}_{\mathrm{R}}=89.44$ \\
\hline
\end{tabular}

\subsection{Input Wave Analysis}

In test runs, due to short length of the flume, maximum of five waves have been observed before they become chaotic standing waves. Wave heights - in order to execute overtopping - are rather large, and the resulting standing waves reach the breaking limit in which state the antinodes freefall at $g$ acceleration. In these circumstances wave profiles are too disturbed to analyze.

Among the five different revetments that have been experimented here, it is understood that the simple slope creates the least wave reflection. In conclusion, the "input" wave profiles are extracted from this setup. Also the wave parameters including wave length, height and period, in each test run, are read for the second wave that approaches the slope structure. Input wave profiles are seen in Figs. $2 \mathrm{a}$ to $2 \mathrm{f}$, and data in Table 3. Wave period $\mathrm{T}$ has been observed from high-speed images. Frame rates are 20 frames per second therefore the precision of these are $0.05 \mathrm{sec}$. 
Table 3. Input waves that are used in tests

Water Flap Flap Wave Wave Wave Cycles Test

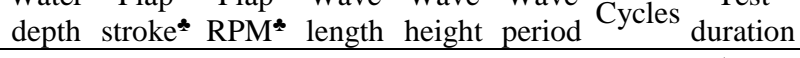

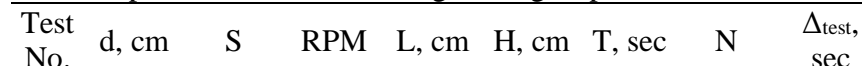

\begin{tabular}{ccccccccc} 
No. & & & & & & & sec \\
\hline 1 & 15 & max & max & 94 & 6 & 0.9 & 4 & 4 \\
\hline 2 & 15 & mid & mid & 82 & 7.5 & 0.75 & 5 & 4 \\
\hline 3 & 15 & mid & low & 52 & 5 & 0.6 & 8 & 5 \\
\hline 4 & 13 & max & max & 88 & 6 & 0.9 & 4 & 4 \\
\hline 5 & 13 & mid & mid & 73 & 6 & 0.75 & 6 & 5 \\
\hline 6 & 13 & mid & low & 56 & 4.5 & 0.6 & 8 & 5 \\
\hline
\end{tabular}

* the control box for two parameters flap stroke and its frequency

used dimmer switches, hence the setting of their input values could continuously vary from a minimum to a maximum.

2a.

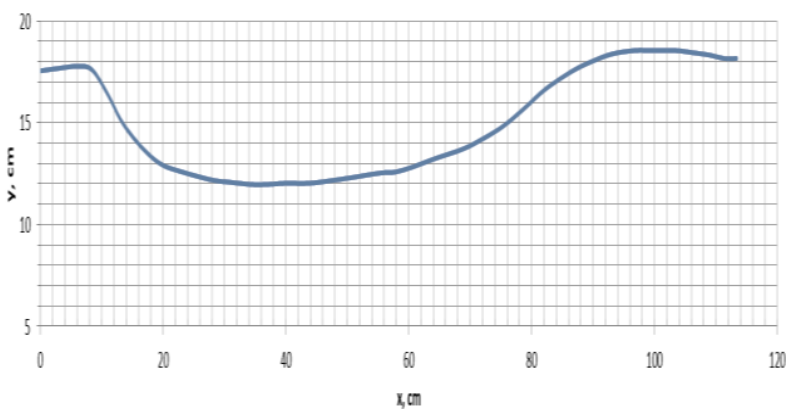

2 b.

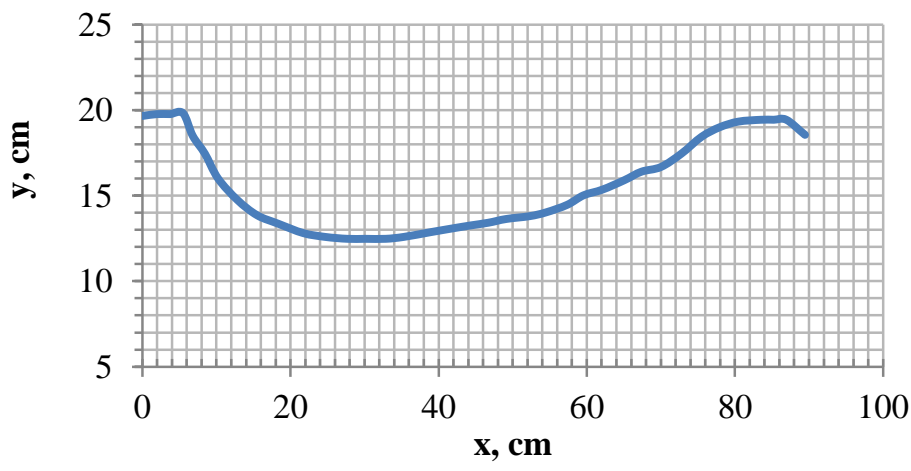

2c.

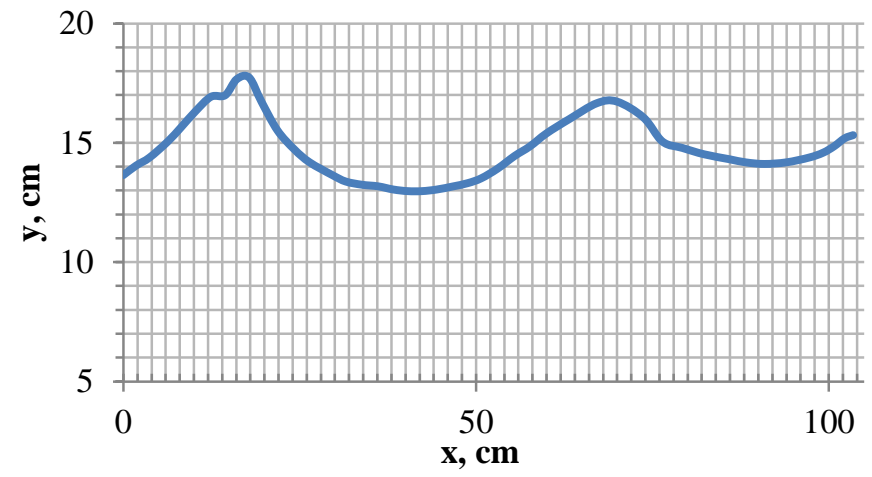

2d.

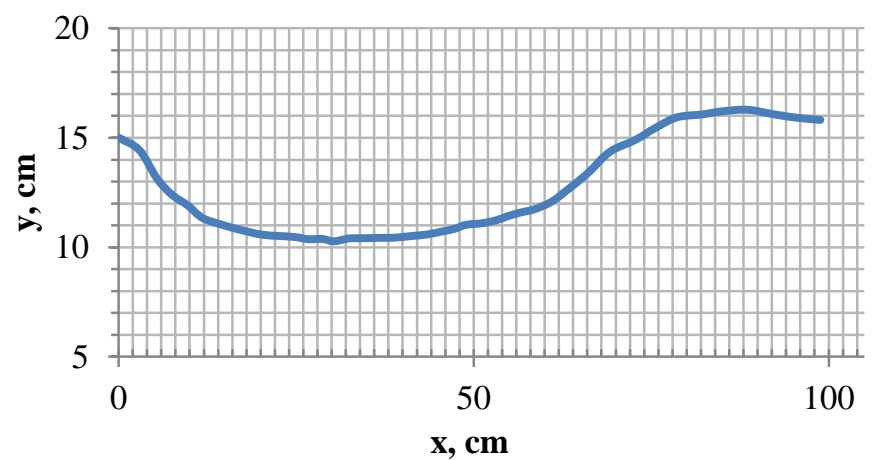

2E.

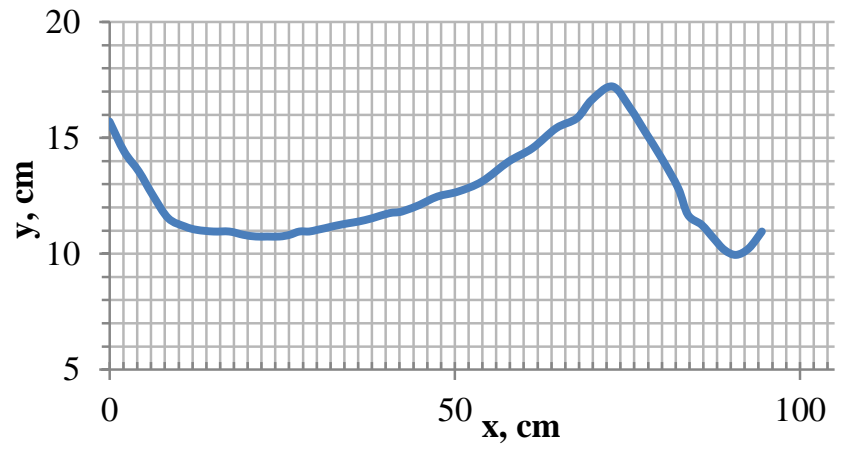

2F.

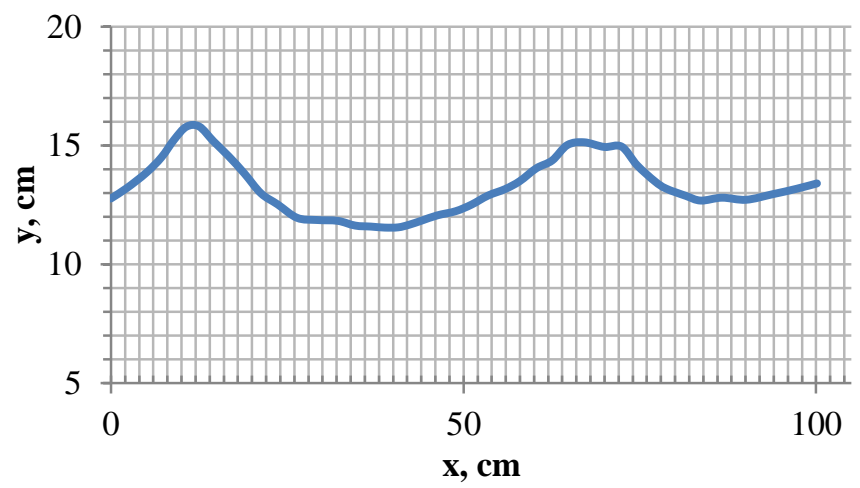

Figure 2. Input waves; water surface from high-speed images has been captured using web-based image processing software [12]

\section{Results and Discussion}

\subsection{Results of Wave Overtopping Experiments}

In this subsection the main outputs of the research for wave overtopping is presented. Water discharge that is measured for each test is divided by the test duration; the resulting value is the overtopping discharge per second per unit length of structure.

Table 4 shows the overtopping discharge Q that has been measured in $\mathrm{ml}$ for different revetments.

Fig. 3 shows $\mathrm{Q}^{*}$ in $\mathrm{ml} \cdot \mathrm{s}^{-1} \cdot \mathrm{m}^{-1}$.

In Fig. 4 the same data are shown in prototype scale in liters per second per unit length of structure assuming 1:20 scale. Still water level at structure toe would be three meters in this scale.

Eventually, Fig. 5 shows the normalized overtopping as Q* is divided by the hydraulic number of the wave height $\sqrt{g H^{3}}$. All diagrams have the relative freeboard on their $\mathrm{x}$-axis.

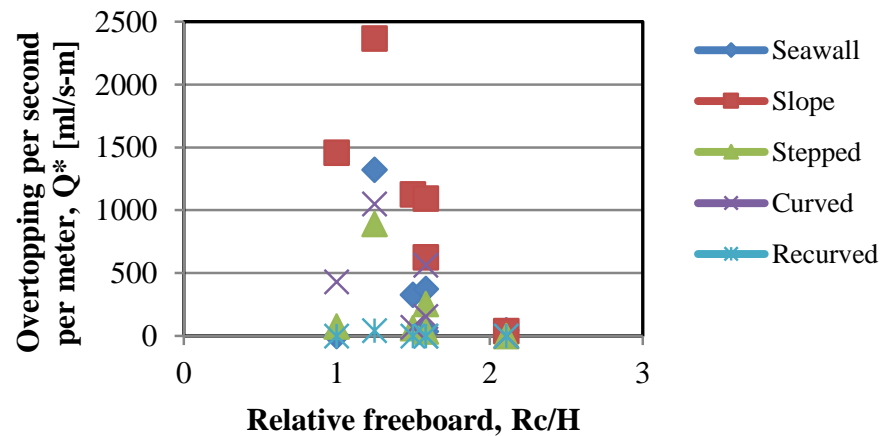

Figure 3. the measured wave overtopping 


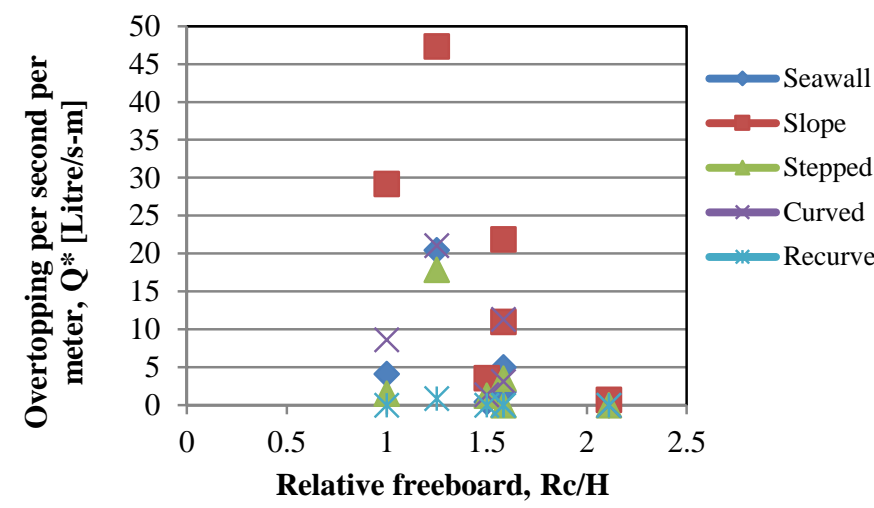

Figure 4. Wave overtopping in prototype scale

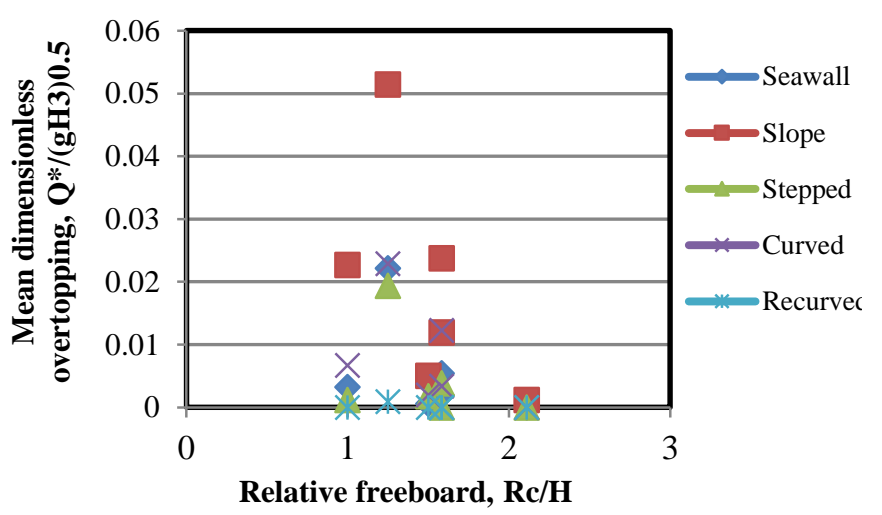

Figure 5. nondimensional wave overtopping

\subsection{Comparing test results with Owen's formula}

In order to verify the present results, use is made of Owen's formula which was introduced in section 1 of this paper Eq. (3). For a reminder it is written below:

$\frac{q}{g H_{S} T_{0 m}}=\mathrm{a} \exp \left(-\mathrm{b} \frac{R_{c}}{H_{s}} \sqrt{\frac{S_{0 m}}{2 \pi}} \frac{1}{\gamma_{r}}\right)$

Where $s_{0 m}$ is the mean wave steepness in deep water, $T_{0 m}$ is the period of a peak in wave spectrum for irregular waves which is substituted with wave period of the regular waves here, and $\gamma_{\mathrm{r}}$ is a parameter for roughness and porosity of the surface which is unity for a smooth and impermeable structure as was used here. Coefficients $\mathrm{a}$ and $\mathrm{b}$ depend on structure's slope. So for the present model slope $1: 1.5$, we use $a=0.01$ and $b=20$ (see Table 1).

Table 5 is a summary of wave parameters and the resulting wave overtopping discharge of the slope structure from Owen's formula as well as test results. Also see Fig. 6 for exponential curve fits to data of Table 5. It is proved that the results are acceptably in the same range. The exponential relationship $\mathrm{Q}=\mathrm{a} * \exp (-\mathrm{b} * \mathrm{R})$, according to [2], has been fitted to both sets of data using Excel ${ }^{\mathrm{TM}}$ built-in editor. The curves are closely the same, although one should note that the regression to the present test data is less favorable with R-square equal to 0.655 than Owen's formula with R-square of 0.865 . This is due to more scatter in test data. In fact, Owen's formula, for an equal value of nondimensional freeboard height, is not too sensitive to wave slope.

Table 5. Wave overtopping calculated by Owen's formula in comparison to present test data

\begin{tabular}{|c|c|c|c|c|c|c|c|}
\hline \multirow{2}{*}{$\begin{array}{l}\text { Water } \\
\text { depth, } \\
\text { d } \\
(\mathrm{cm})\end{array}$} & \multirow{2}{*}{$\begin{array}{l}\text { Wave } \\
\text { length, } \\
\text { L }\end{array}$} & \multirow{2}{*}{$\begin{array}{c}\text { Wave } \\
\text { height, } \\
\text { H }\end{array}$} & \multirow{2}{*}{$\begin{array}{l}\text { Wave } \\
\text { period, } \\
\mathrm{T}(\mathrm{sec})\end{array}$} & \multirow{2}{*}{$\begin{array}{c}\text { Wave } \\
\text { steepness } \\
\text { s=H/L }\end{array}$} & \multicolumn{3}{|c|}{$\mathrm{Q}^{*} /\left(\mathrm{gH}^{3}\right)^{0.5}$} \\
\hline & & & & & $\mathrm{R}_{\mathrm{c}} / \mathrm{H}^{-}$ & $\begin{array}{l}\text { Owen's } \\
\text { formula }\end{array}$ & $\begin{array}{c}\text { Present } \\
\text { test }\end{array}$ \\
\hline 15 & 94 & 6 & 0.9 & 0.064 & 1.25 & 0.0332 & 0.0514 \\
\hline 15 & 82 & 7.5 & 0.75 & 0.091 & 1 & 0.0329 & 0.0227 \\
\hline 15 & 52 & 5 & 0.6 & 0.096 & 1.5 & 0.0054 & 0.0051 \\
\hline 13 & 88 & 6 & 0.9 & 0.068 & 1.58 & 0.0120 & 0.0120 \\
\hline 13 & 73 & 6 & 0.75 & 0.082 & 1.58 & 0.0094 & 0.0237 \\
\hline 13 & 56 & 4.5 & 0.6 & 0.080 & 2.11 & 0.0017 & 0.0012 \\
\hline
\end{tabular}

Table 4. test measurements for wave overtopping for different revetments

\begin{tabular}{|c|c|c|c|c|c|c|c|c|c|c|c|c|c|}
\hline & & & & & & & & & & & & $\begin{array}{l}\text { Wave } \\
\text { Inputs }\end{array}$ & $\begin{array}{l}\text { Overtopping } \\
\text { Results (ml) }\end{array}$ \\
\hline $\begin{array}{l}\text { Test } \\
\text { No. }\end{array}$ & $\begin{array}{l}\mathrm{d}, \\
\mathrm{cm}\end{array}$ & $S$ & RPM & $\begin{array}{l}\mathrm{L}, \\
\mathrm{cm}\end{array}$ & $\begin{array}{l}\mathrm{H}, \\
\mathrm{cm}\end{array}$ & $\begin{array}{l}\mathrm{T}, \\
\mathrm{sec}\end{array}$ & $\mathrm{N}$ & $\begin{array}{l}\mathrm{T}_{\text {test}}, \\
\text { sec }\end{array}$ & $Q_{\text {seawall }}$ & $\mathrm{Q}_{\text {slope }}$ & $\mathrm{Q}_{\text {stepped }}$ & $\mathrm{Q}_{\text {curved }}$ & $Q_{\text {recurved }}$ \\
\hline \multirow{2}{*}{1} & \multirow{2}{*}{15} & \multirow{2}{*}{$\max$} & \multirow{2}{*}{$\max$} & \multirow{2}{*}{94} & \multirow{2}{*}{6} & \multirow{2}{*}{0.9} & \multirow{2}{*}{4} & \multirow{2}{*}{4} & 1200 & \multirow{2}{*}{2840} & 1118 & 1270 & 40 \\
\hline & & & & & & & & & $1250 *$ & & 1024 & 1254 & 62 \\
\hline \multirow{2}{*}{2} & \multirow{2}{*}{15} & \multirow{2}{*}{ mid } & \multirow{2}{*}{ mid } & \multirow{2}{*}{82} & \multirow{2}{*}{7.5} & \multirow{2}{*}{0.75} & \multirow{2}{*}{5} & \multirow{2}{*}{4} & 225 & \multirow{2}{*}{1750} & 104 & 510 & \multirow{2}{*}{0} \\
\hline & & & & & & & & & 270 & & 80 & 525 & \\
\hline \multirow{2}{*}{3} & \multirow{2}{*}{15} & \multirow{2}{*}{ mid } & \multirow{2}{*}{ low } & \multirow{2}{*}{52} & \multirow{2}{*}{5} & \multirow{2}{*}{0.6} & \multirow{2}{*}{8} & \multirow{2}{*}{5} & 60 & \multirow{2}{*}{265} & \multirow{2}{*}{94} & 118 & \multirow{2}{*}{0} \\
\hline & & & & & & & & & 0 & & & 86 & \\
\hline \multirow{2}{*}{4} & \multirow{2}{*}{13} & $\max$ & $\max$ & 88 & 6 & 09 & 4 & 4 & 300 & 1328 & 210 & 650 & 0 \\
\hline & & $\max$ & $\max$ & 80 & 0 & 0.9 & 4 & 4 & 300 & 1295 & 210 & 704 & 0 \\
\hline 5 & 13 & mid & $\operatorname{mid}$ & 73 & 6 & 075 & 6 & 5 & 150 & 810 & 0 & 246 & 0 \\
\hline 5 & 13 & mid & mid & 13 & 0 & 0.15 & 0 & 5 & 108 & 840 & 0 & 220 & 0 \\
\hline 6 & 13 & $\operatorname{mid}$ & low & 56 & 45 & 06 & 8 & 5 & 0 & 66 & 0 & - & 0 \\
\hline & & & & & & & & $J$ & 0 & 40 & 0 & - & 0 \\
\hline
\end{tabular}

Cells with two values are a replication of the same test. 


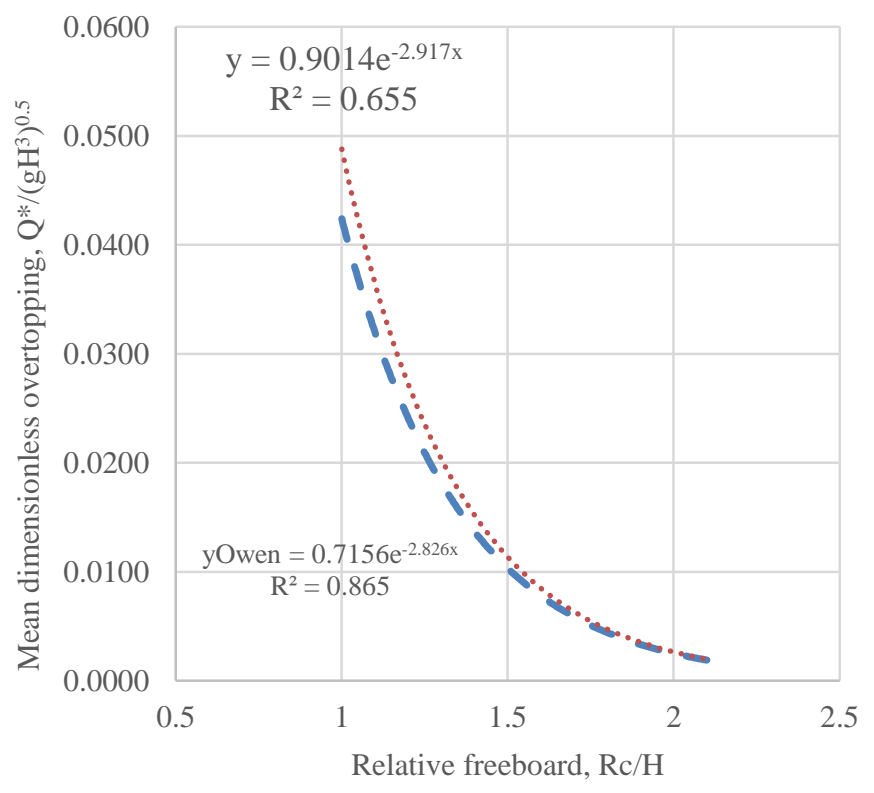

Fig. 6. Comparison between Owen's formula and test data for the slope structure 1:1.5

\subsection{Estimation of Overtopping Velocity}

Successive images of the wave run-up on slope 1:1.5 were observed and with the aid of a graded ruler that was put on flume surface, using web-based software [12], water surface was captured and plotted in Matlab $^{\mathrm{TM}}$ as seen alongside every image in Fig. 7.

Landward of the seawall is set the origin of the coordinates along horizontal and on the seabed along vertical.

Extents of the water surface in the images are from 70 $\mathrm{cm}$ seaward to minus six centimeters landward. Seawall crest height is $+22.5 \mathrm{~cm}$, while still water level (SWL) in this specific run was $+13 \mathrm{~cm}$ above seabed. The highest point of continuum water surface was about $+24 \mathrm{~cm}$ above seabed, while water splash was as high as $+27 \mathrm{~cm}$. As a result, overtopping water depth on seawall's crest was:

$h_{c}=24-22.5=1.5 \mathrm{~cm}$.

In order to calculate the speed of wave run-up on seaward slope of the structure Table 6 is referenced. Distance that the wave run-up tongue travels on the slope is calculated as follows:

$$
\Delta \mathrm{S}=\sqrt{\Delta \mathrm{x}^{2}+\Delta \mathrm{y}^{2}}
$$

Wave run-up speed on seaward slope of the structure is therefore:

$$
\mathrm{u}_{\mathrm{A}}=\Delta \mathrm{S} / \Delta \mathrm{t}
$$

where $\Delta \mathrm{t}$ is the time between successive frames that is $0.05 \mathrm{sec}$.

Table 6. wave run-up kinematics

\begin{tabular}{ccccc}
\hline Frame No. & $\mathrm{x}, \mathrm{cm}$ & $\mathrm{y}, \mathrm{cm}$ & $\Delta \mathrm{S}, \mathrm{cm}$ & $\mathrm{u}_{\mathrm{A}} \mathrm{m} / \mathrm{s}$ \\
\hline 44 & 25 & 11 & - & - \\
\hline 45 & 19 & 15 & 7.21 & 1.44 \\
\hline 46 & 11.5 & 20 & 9.01 & 1.80 \\
\hline 47 & 7 & 23 & 5.41 & 1.08 \\
\hline
\end{tabular}

Overtopping velocity is determined at the beginning of the dike crest, which is seen in frame No. 47. According to last row of Table 6 , this velocity is $u_{c}=1.08 \mathrm{~m} / \mathrm{s}=108$ $\mathrm{cm} / \mathrm{s}$. (index A used for seaward slope and index $\mathrm{C}$ for crest [4]).

Summing up, water discharge is calculated as follows:

$$
\mathrm{Q}=\left(\mathrm{u}_{\mathrm{c}} \times \mathrm{h}_{\mathrm{c}}\right) / 0.3 \mathrm{~m}=\underset{\mathrm{ml} /(\mathrm{s} . \mathrm{m}) .}{(108 \mathrm{~cm} / \mathrm{s} \times 1.5 \mathrm{~cm}) / 0.3 \mathrm{~m}=540}
$$

In the above calculation, $0.3 \mathrm{~m}$ is the length of the structure. This result is in close agreement with the measured discharge as was reported in Table 4 and Fig. 3.
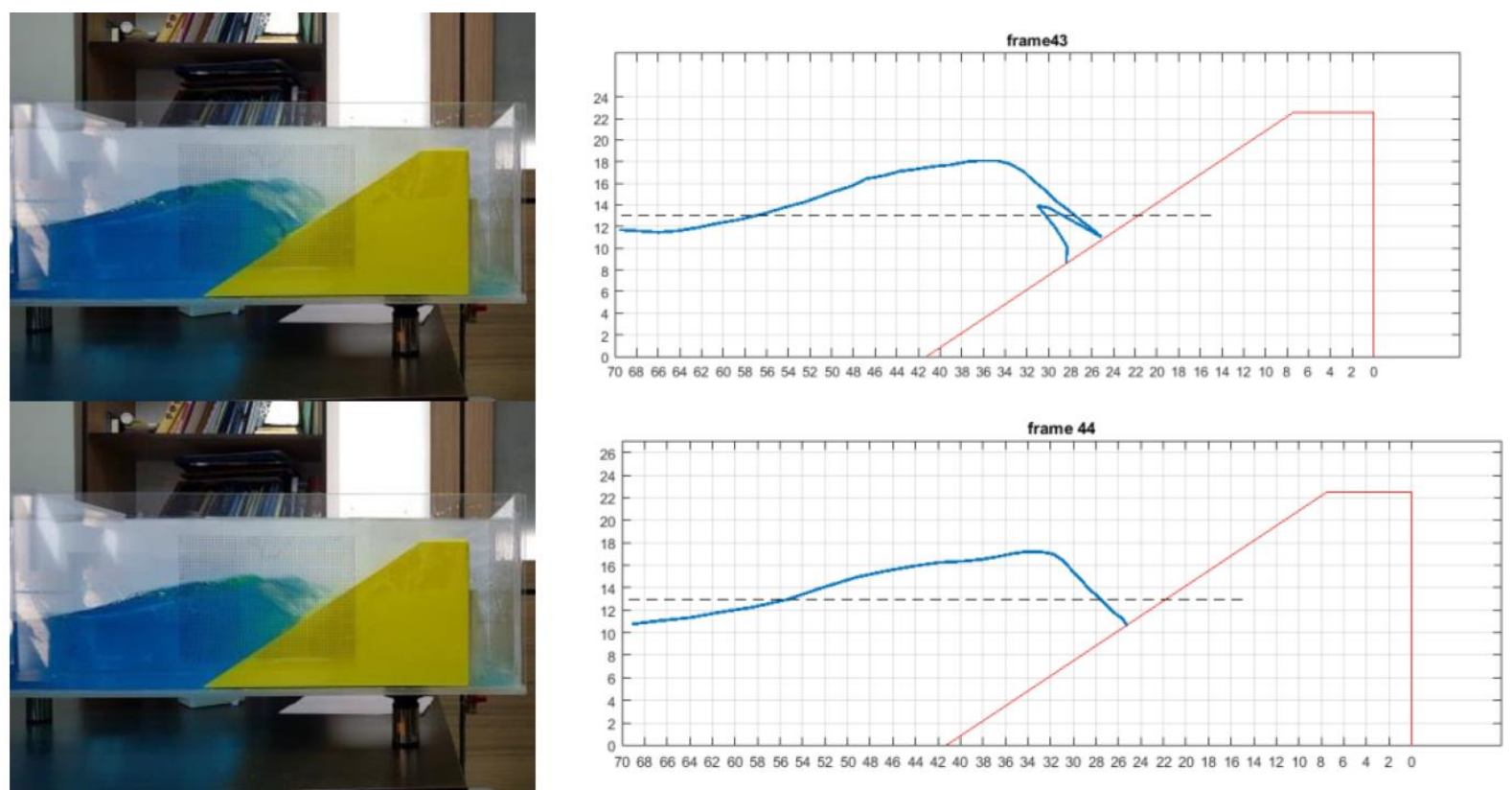

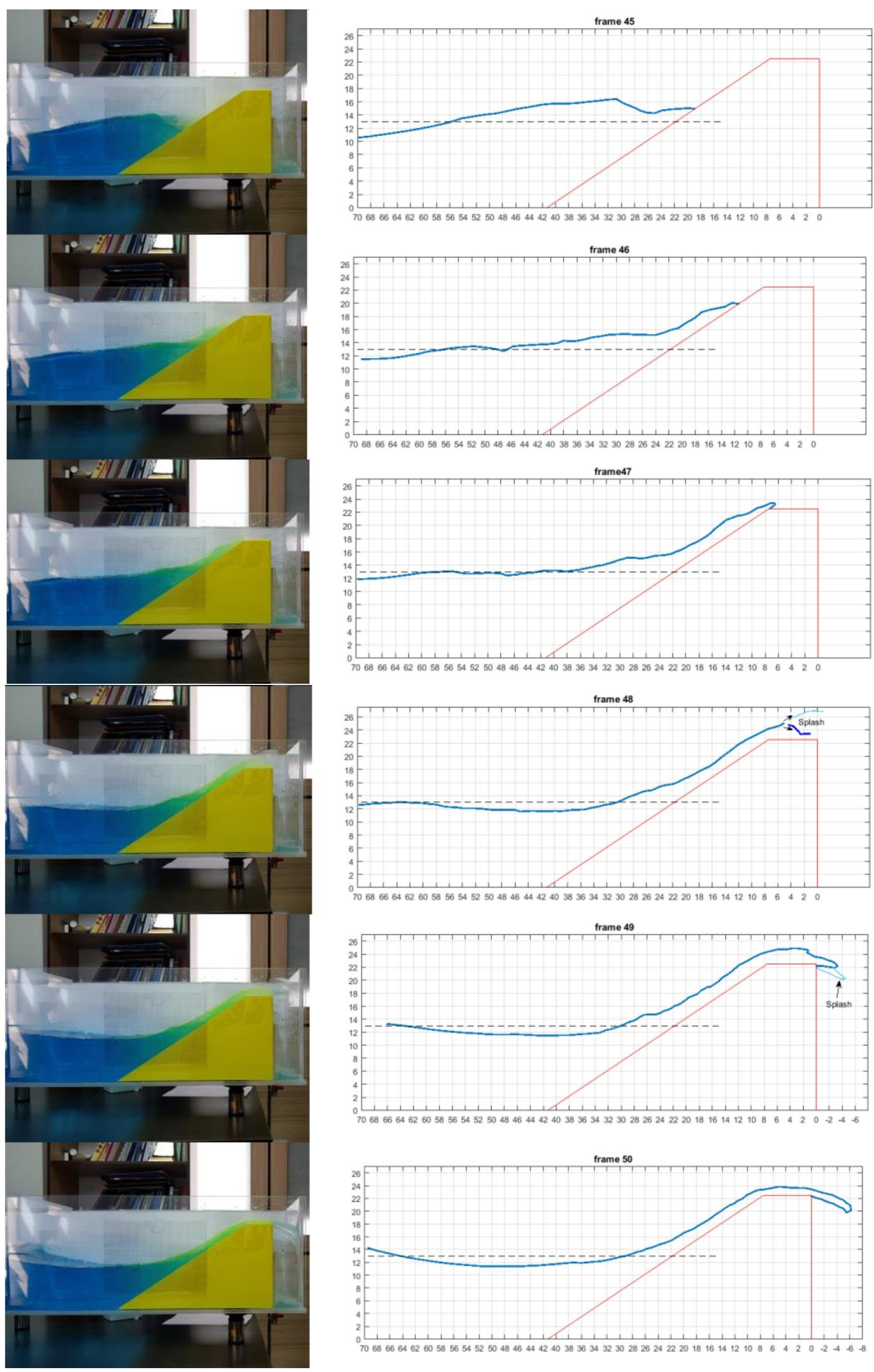

70686664626058565452504846444240383634323028262422201816141210866420
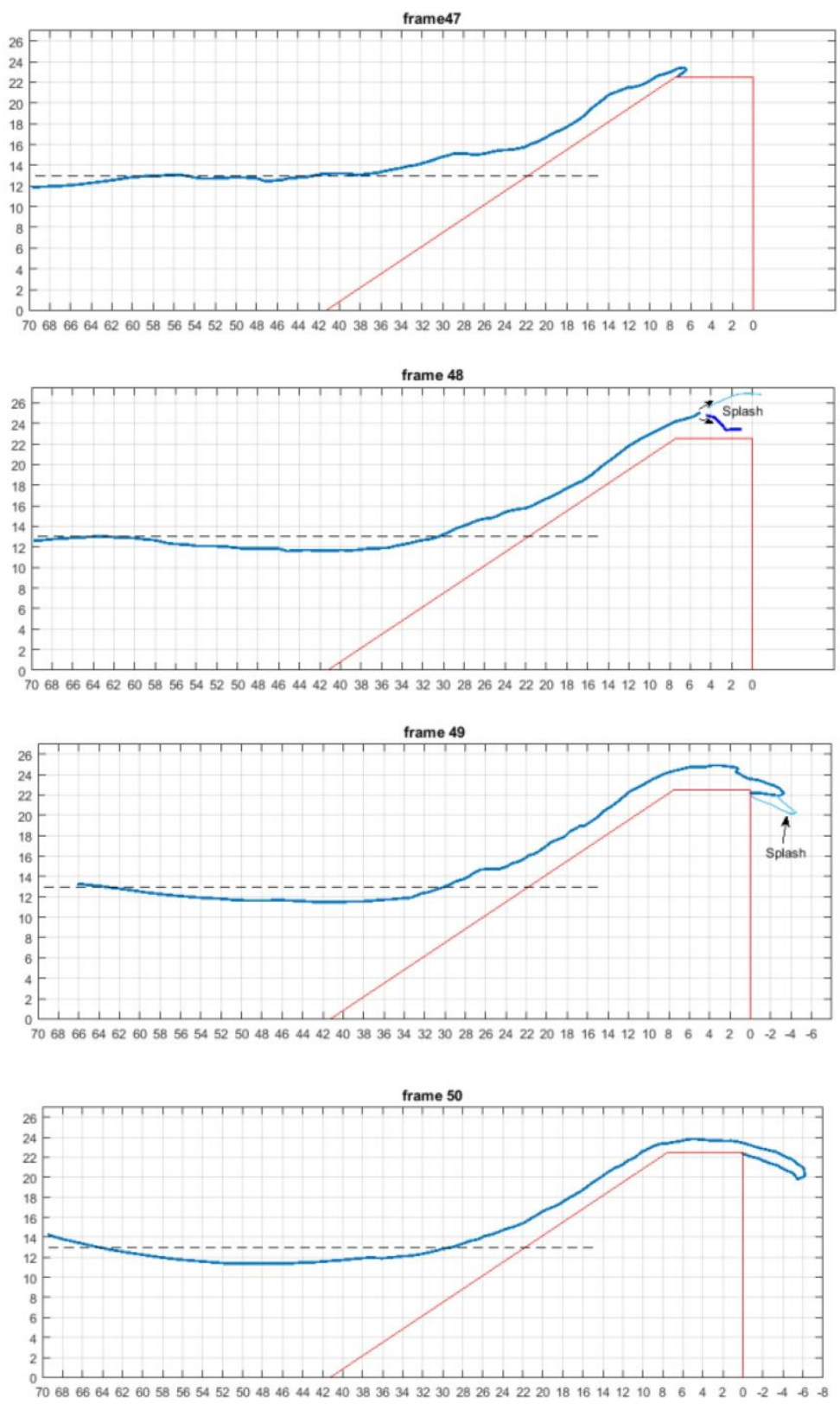

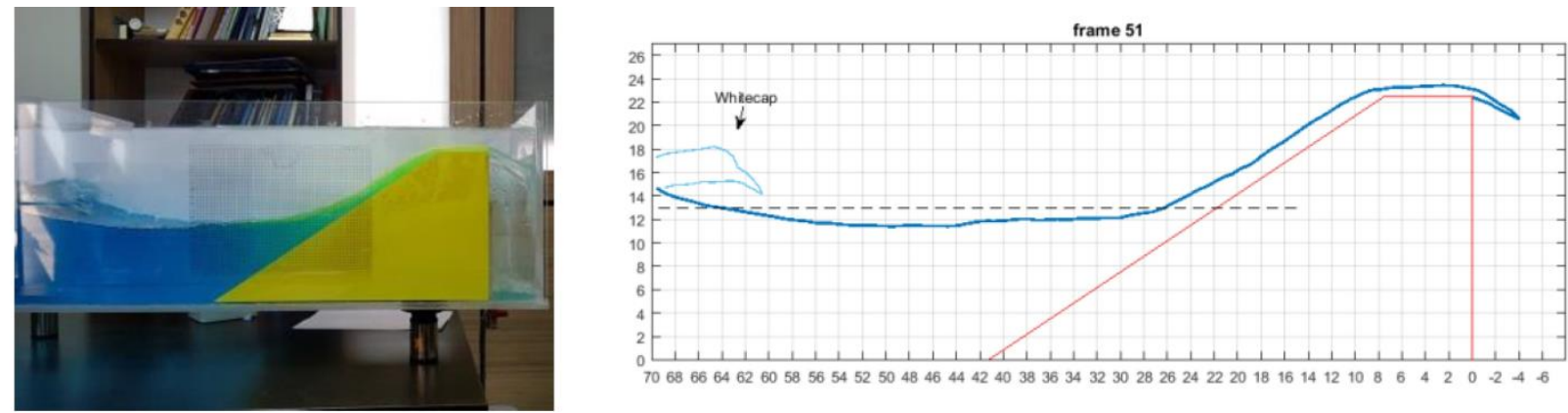

Figure 7. Wave run-up on slope 1:1.5, $\mathrm{SWL} 13 \mathrm{~cm}, \mathrm{~T}=0.75 \mathrm{sec}, \mathrm{H}=6 \mathrm{~cm}$. Time step between successive frames is $0.05 \mathrm{sec}$

\section{Conclusions}

For the safety and protection of coastal regions it is important to properly design revetments and seawalls which can reduce wave overtopping. Except than rubble-mound structures which demonstrate efficient ways to dissipate the incoming wave energy, seawalls of different types have been in common use all around the world. In the present research, five different structures: vertical seawall, slope, stepped slope, curved-face seawall and recurved were experimented. The tests were performed in a small portable wave flume that is $2 \mathrm{~m}$ in length and 30 by $30 \mathrm{~cm}$ in cross section. Water depth of 15 and $13 \mathrm{~cm}$ were used which correspond to respectively 3 and $2.6 \mathrm{~m}$ water depth at the structure toe in a 1:20 scale. These values are very typical for coastal constructions.

Present test results were graphically and in tabulated format were presented. These are consistent with previously published data. In addition, the present results can simply compare the effectiveness of different designs of a seawall in reducing the wave overtopping. The small size of the wave flume makes it a very good candidate for educational demos in a classroom. Also the quantities measured in this scale provide an initial insight for designing a large scale experiment or a numerical CFD (computational fluid dynamics) modeling and simulation.

Finally some suggested future works are as follows:

- Optimization of seawall dimensions with the aid of experiment and CFD in order to minimize wave overtopping.

- Installation of a submerged reef in front of the seawall to further dissipate wave energy.

- Installation of rubble-mound structure and armor units over the slope in order to study the pore pressures and their action on wave overtopping.

\section{References}

1. Dean, R. G. and Dalrymple, R. A., (1991), Water wave mechanics for engineers and scientists, World Scientific Publishing.

2. CEM, (2002), Coastal Eng. Manual, USACE, EM 1110-2-1100 (Part VI).

3. McCormick, M. E., (2010), Ocean engineering mechanics, New York: Cambridge University Press.
4. Schuttrumpf, H. and van Gent, M.R.A. (2003), Wave Overtopping at Seadikes, Coastal Structures Conference, Portland, Oregon, United States.

5. Owen, M. W., (1980), Design of Seawalls Allowing for Wave Overtopping, Wallingford, UK Hydraulics Research Station, Report No. 924.

6. Owen, M. W., (1982), The Hydraulic Design of Seawall Profiles, Proceedings of the Coastal Protection Conference, Institution of Civil Engineers, Thomas Telford Publishing, London, UK.

7. Allsop, N.W.H., et al., (2008), Improvements in wave overtopping analysis: the EurOtop overtopping manual and calculation tool, COPEDEC VII. pp. 1-14, Dubai.

8. Van de Walle, B., (2003), Wave run-up on rubble mound breakwaters, $\mathrm{PhD}$ thesis, Ghent University, 2003.

9. Mariani, A., et al., (2009), Wave Overtopping of Coastal Structures. Physical Model versus Desktop Predictions, Journal of Coastal Research, pp. 534-538. 10. JBA trust. JBA Trust Wave Tank. [Online] 2018. www.jbatrust.org.

11. USACE, (1984), Shore Protection Manual Voume II, Vicksburg, Mississippi : Coastal Engineering Research Center.

12. GNU Affero. Automeris. [Online] 2019. https://apps.automeris.io/wpd/. 